\title{
Cytotoxic Activity of Red Fruit (Pandanus conoideus Lam.) Oil and Its Effect On Cyclooxygenase-2 Gene Expression in Raji Cells
}

\author{
Fen Tih \\ Department of Biochemistry \\ Faculty of Medicine, Maranatha Christian University \\ Jl. Prof. Drg. Suria Sumantri MPH NO.65 Bandung 40164 Indonesia \\ Email :fentihfk@gmail.com
}

\begin{abstract}
The number of cancer patient is increasing, while a really effective therapy has not yet been discovered. One concept of carcinogenesis is the relation between chronic inflammation and cancer. Cyclooxygenase-2 (COX-2) has a carcinogenic effect in inflamed and malignant tissues. Red Fruit contains carotenoid that can suppress COX-2 gene expression and tocopherol, which is a potent inhibitor of COX-2. The purpose of this study is to determine cytotoxic activity of Red Fruit oil and its effect on COX-2 gene expression. The experiment used 5 dosages of Red Fruit, 100, 200, 300, 400, and $500 \mu \mathrm{g} / \mathrm{mL}$, exposed to Raji cells. However, unexposed Raji cells were used as control. Cytotoxic activities were evaluated by MTT Assay, while Lethal Concentration ${ }_{50}\left(L C_{50}\right)$ was determined through regression-correlation analysis. Red Fruit oil effect on COX-2 gene expression was evaluated by Reversed Transcriptase Chain Reaction (RT-PCR) method and electrophoresis. Electrophoresis bands were analyzed by Scion Image for Windows. Optical Integrated Density (OID) of unexposed and exposed groups were statistically analyzed with one way Analysis of Variance (ANOVA), followed by Duncan test with $\alpha=0.05$. The results showed that Red Fruit had a cytotoxic activity on Raji cells with $L C_{50}$ of $331.42 \mu \mathrm{g} / \mathrm{mL}$. Red Fruit suppressed COX-2 gene expression with an effective dosage obtained at $500 \mu \mathrm{g} / \mathrm{mL}$.
\end{abstract}

Keywords: red fruit, cytotoxicity, cox-2 gene expression, raji cells 


\title{
Aktivitas Sitotoksik Minyak Buah Merah (Pandanus conoideus Lam.) dan Inhibisi Ekspresi Gen Siklooksigenase-2 (Cox-2) pada Sel Raji
}

\author{
Fen Tih \\ Fakultas Kedokteran, Universitas Kristen Maranatha \\ J1. Prof. Drg. Suria Sumantri MPH NO.65 Bandung 40164 Indonesia \\ Email : fentihfk@gmail.com
}

\begin{abstract}
Abstrak
Jumlah penderita kanker semakin banyak sedangkan cara pengobatan yang benar-benar efektif belum ditemukan. Salah satu konsep mengenai karsinogenesis adalah hubungan antara inflamasi kronis dengan karsinogenesis. Enzim yang memiliki efek karsinogenik dan aktif pada jaringan yang mengalami inflamasi dan malignansi adalah siklooksigenase-2 (COX-2). Buah Merah mengandung karotenoid yang dapat menekan ekspresi gen COX-2 dan vitamin $\mathrm{E}$ (tokoferol) yang merupakan inhibitor poten terhadap COX-2. Penelitian ini bertujuan mengetahui aktivitas sitotoksik minyak Buah Merah dan efeknya terhadap ekspresi gen COX-2. Penelitian ini menggunakan minyak Buah Merah (BM) dengan dosis 100, 200, 300, 400, dan $500 \mu \mathrm{g} / \mathrm{mL}$ yang diberikan pada Sel Raji dibandingkan dengan sel yang tidak diberi perlakuan. Aktivitas sitotoksisitas BM diuji dengan metode MTT Assay dan ditentukan Lethal Concentration $_{50}\left(\mathrm{LC}_{50}\right)$ melalui analisis regresi-korelasi. Efek BM terhadap ekspresi gen COX-2 dinilai dengan Reversed Transcriptase Chain Reaction (RT-PCR) yang dilanjutkan dengan elektroforesis, hasil dokumentasi dianalisis dengan Scion Image for Windows. Optical Integrated Density (OID) kelompok kontrol dan perlakuan dibandingkan dengan metode Analisis Varian (ANAVA) satu arah kemudian dilanjutkan dengan uji Duncan $(\alpha=0,05)$. Hasil penelitian menunjukkan bahwa BM bersifat sitotoksik terhadap Sel Raji dengan $\mathrm{LC}_{50}$ sebesar $331,42 \mu \mathrm{g} / \mathrm{mL}$. Buah Merah dapat menekan ekspresi gen COX-2 pada Sel Raji dengan dosis efektif sebesar $500 \mu \mathrm{g} / \mathrm{mL}$.
\end{abstract}

Kata kunci: buah merah, sitotoksisitas, ekspresi gen cox-2, sel raji 


\section{Pendahuluan}

Kanker merupakan masalah kesehatan yang serius di Indonesia. Pada suatu penelitian epidemiologik tentang penyakit kanker, diperkirakan terjadi peningkatan 99\% penderita kanker pada tahun 2010 di negara berkembang bila dibandingkan dengan pada tahun 1985. Di Indonesia terlihat lonjakan kejadian kanker yang besar dengan jumlah kematian yang tinggi. Setiap tahun diperkirakan terdapat 190.000 penderita baru dan seperlimanya akan meninggal akibat penyakit ini. ${ }^{1}$

Kanker merupakan penyakit yang mendapat perhatian serius dalam dunia kedokteran, karena jumlah penderita semakin banyak sedangkan cara pengobatan yang benar-benar efektif belum ditemukan. Berbagai metode terapi penyakit kanker telah banyak dilakukan, salah satunya adalah kemoterapi. Senyawa kemoterapi dapat menghambat pertumbuhan kanker melalui penghambatan proliferasi atau membunuh sel kanker tersebut. Kelemahan metode ini adalah kesulitan dalam mendesain senyawa kemoterapi yang mempunyai aktivitas antikanker tinggi dan mempunyai efek samping yang rendah terhadap sel normal. ${ }^{2}$ Kesulitan ini menyebabkan banyak peneliti mengembangkan konsep-konsep mengenai karsinogenesis untuk mencari berbagai alternatif terapi kanker. Salah satu konsep yang dikembangkan adalah hubungan antara inflamasi dengan karsinogenesis, terutama inflamasi kronis. Inflamasi kronis diidentifikasi sebagai faktor risiko untuk kanker, bahkan sebagai faktor untuk menentukan prognosis atau diagnosis kanker pada stadium dini. Beberapa contoh hubungan antara kanker dengan inflamasi mencakup infeksi Human papiloma virus (HPV) dengan kanker serviks, infeksi bakteri Helicobacter pylori dengan adenokarsinoma gaster, infeksi virus Hepatitis $B$ dengan karsinoma hepatoselular, infeksi Schistosoma haematobium dengan karsinoma kandung kemih, serta inflamasi oleh asbestos dan karsinoma bronkogenik atau mesotelioma. ${ }^{3}$

Enzim yang memiliki efek karsinogenik dan aktif pada jaringan yang mengalami inflamasi dan malignansi adalah siklooksigenase-2 (COX-2). Prostaglandin hasil aktivitas COX-2 dinyatakan terlibat dalam karsinogenesis melalui perangsangan proses proliferasi sel, angiogenesis, dan penghambatan apoptosis. ${ }^{4}$ Sejumlah penelitian menunjukkan tingginya kadar COX-2 pada keganasan di usus besar, kelenjar prostat, payudara, kelenjar pankreas, paru-paru, kandung kemih, endometrium, kulit, dan limfosit. ${ }^{5}$ Tingginya kadar COX-2 dihubungkan dengan tingkat progresivitas dan metastasis berbagai jenis kanker. ${ }^{6}$

Penggunaan inhibitor COX-2 selektif untuk menurunkan insidensi kanker telah terbukti secara laboratoris dan klinis. ${ }^{5,7}$ Kombinasi inhibitor COX-2 selektif dengan terapi antikanker tradisional memiliki efek aditif atau sinergis yang lebih menguntungkan dibanding monoterapi. ${ }^{8}$ Tetapi pada tahun 2004 salah satu jenis inhibitor COX-2 selektif ditarik dari peredaran karena 


\section{Research Article}

ternyata pada penggunaan jangka panjang ditemukan peningkatan serangan kardiovaskular fatal dan non-fatal (kematian karena kardiovaskular, serangan jantung, stroke, dan gagal jantung) sebesar 2,5 kali lipat dibandingkan dengan pemakai plasebo. ${ }^{7}$ World Health Organization bahkan telah mengeluarkan aturan untuk membatasi penggunaan inhibitor COX-2 selektif ini. ${ }^{9}$

Kesulitan ini menyebabkan penelitian untuk mencari senyawa yang dapat menekan sintesis COX-2 secara selektif yang berasal dari bahan alam banyak dikembangkan. Identifikasi senyawa dari bahan alam yang berpotensi sebagai penekan sintesis COX-2 menjadi harapan baru. Berbagai senyawa tumbuhan seperti golongan karotenoid dan vitamin E banyak diteliti dan kemungkinan mempunyai aktivitas menekan sintesis COX-2. ${ }^{2}$

Indonesia kaya akan bahan alam, yang salah satu pemanfaatannya adalah sebagai bahan obat. Salah satu tumbuhan yang ekslusif hanya tumbuh di Indonesia dan banyak diteliti tentang aktivitasnya sebagai antikanker adalah Pandanus conoideus Lam. (Buah Merah). Penelitian terdahulu menunjukkan bahwa ekstrak Buah Merah dapat menekan pertumbuhan sel kanker paru. ${ }^{10}$ Ekstrak n-heksan Pandanus conoideus Lam. dapat menghambat pertumbuhan sel tumor kelenjar susu. ${ }^{11}$ Secara in-vivo, ekstrak Pandanus conoideus Lam. dapat menghambat proses tumorigenesis pada paru tikus yang diinduksi karsinogen DMBA (Dimetilbenz(a)antrasen). ${ }^{12}$

Pandanus conoideus Lam. mengandung carotenoid, suatu golongan senyawa yang diidentifikasi dapat menekan ekspresi gen COX-2. ${ }^{10,13,14}$ Pandanus conoideus Lam. juga mengandung vitamin $\mathrm{E}$ (tokoferol) dengan kadar tinggi yang merupakan inhibitor potensial untuk COX-2. ${ }^{10,15}$ Karena itu, pada penelitian ini diteliti mengenai aktivitas sitotoksik Buah Merah (Pandanus conoideus Lam.) dan kemampuannya dalam menekan ekspresi gen COX-2.

Kultur sel Raji adalah sel limfosit B yang diisolasi dari penderita Limfoma Burkitt, dipilih untuk digunakan sebagai media pada penelitian ini karena memiliki ekspresi COX-2 yang tinggi. ${ }^{4}$

\section{Metode}

Penelitian ini adalah eksperimental laboratorium murni yang bersifat komparatif, dilaksanakan di Lembaga Pusat Penelitian Terpadu Universitas Gadjah Mada (LPPT-UGM) pada Agustus 2009-Juni 2010.

Buah Merah yang digunakan adalah kultivar merah panjang, terlihat segar dan berwarna merah terang, berasal dari Papua. Bahan uji diekstrak secara murni di Laboratorium Farmakognostik Fakultas Farmasi ITB, Bandung. Sebelum digunakan, ekstrak berupa minyak terlebih dahulu dibiarkan dalam suhu ruangan beberapa saat, kemudian dilarutkan dalam medium dan dipersiapkan menjadi 5 dosis berbeda $(100,200,300,400,500 \mu \mathrm{g} / \mathrm{mL})$. 


\section{Research Article}

Sel Raji didapat dari LPPT-UGM. Penumbuhan sel menggunakan media RPMI-1640 dengan penambahan FBS 10\%, Fungison 0,5\% dan penisilin-streptomisin 1\%, dalam inkubator dengan suhu $37^{\circ} \mathrm{C}$ dan $\mathrm{CO}_{2} 5 \%$.

Sitotoksisitas minyak Buah Merah dilakukan dengan dengan MTT Assay. MTT assay merupakan salah satu metode kolorimetrik yang digunakan dalam uji sitotoksik. Metode ini berdasarkan pada perubahan garam tetrazolium (3-(4,5-dimetiltiazol-2-i1)-2,5difeniltetrazolium bromida / MTT) menjadi kristal formazan dalam mitokondria yang aktif pada sel yang masih hidup. MTT diabsorbsi ke dalam sel hidup dan dipecah melalui reaksi reduksi oleh sistem suksinat tetrazolium reduktase dalam rantai respirasi mitokondria menjadi formazan yang terlarut dalam SDS $10 \%$. Kristal formazan ini memberi warna ungu yang dapat dibaca absorbansinya dengan menggunakan ELISA reader. Semakin besar absorbansi menunjukkan semakin banyak jumlah sel yang hidup. ${ }^{38}$

Sebanyak $100 \mu \mathrm{L}$ suspensi sel dengan kepadatan $5 \times 10^{5} \mathrm{sel} / \mathrm{mL}$ dimasukkan ke dalam masing-masing sumur dalam microplate 96 well. Minyak BM dilarutkan dalam medium sehingga memiliki kadar 100, 200, 300, 400 dan $500 \mu \mathrm{g} / \mathrm{mL}$, kemudian dimasukkan ke dalam sumur sebanyak $100 \mu \mathrm{L}$. Kontrol negatif berupa media saja dan kontrol positif berupa sel dan media. Inkubasi dalam inkubator $37^{\circ} \mathrm{C}$ dan $\mathrm{CO}_{2} 5 \%$ selama 24 jam. Larutan MTT konsentrasi 5 $\mathrm{mg} / \mathrm{mL}$ ditambahkan ke dalam masing-masing sumuran sebanyak $10 \mu \mathrm{L}$, kemudian diinkubasi kembali selama 4 jam. Larutan SDS 10\% sebanyak $100 \mu \mathrm{L}$ ditambahkan untuk menghentikan reaksi MTT. Microplate diinkubasi dalam ruang gelap semalam, kemudian dibaca dengan ELISA reader menggunakan panjang gelombang $\lambda 550 \mathrm{~nm}$. Setiap perlakuan diulang sebanyak 5 kali.

Data yang diperoleh berupa absorbansi masing-masing sumur dikonversi ke dalam persen sel mati dengan perhitungan sebagai berikut:

$$
\text { Persentase kematian sel }=\frac{(A-B)-(C-D)}{(A-B)} X 100 \%
$$

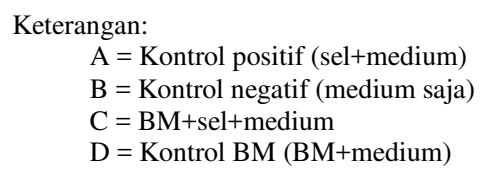

Perhitungan $\mathrm{LC}_{50}$ menggunakan analisis regresi korelasi berdasarkan pada grafik fungsi linier log konsentrasi vs nilai persentase kematian sel akibat pemberian zat uji. Harga $\mathrm{LC}_{50}$ diperoleh dengan memasukkan nilai 50 ke dalam persamaan garis lurus. ${ }^{16}$ 


\section{Research Article}

Efek minyak Buah Merah terhadap ekspresi gen COX-2 pada sel Raji dianalisis dengan RT-PCR. Sebanyak $1 \mathrm{~mL}$ suspensi sel dengan kepadatan $5 \times 10^{5} \mathrm{sel} / \mathrm{mL}$ dimasukkan ke dalam sumur dalam plate 24 well, ditambah $1 \mathrm{~mL}$ minyak Buah Merah dengan 5 dosis yang berbeda. Kelompok kontrol berupa sel Raji dan medium. Plate diinkubasi dalam inkubator $5 \% \mathrm{CO}_{2}$ selama 24 jam pada suhu $37^{\circ} \mathrm{C}$. Kemudian RNA diisolasi dengan reagen Trizol. Kualitas RNA yang telah diisolasi diukur dengan elektroforesis dan spektrofotometri.

RT-PCR untuk mRNA COX-2 menggunakan primer Forward 5'TAAGCACATCGCATACTCTG3', Reverse 5'AAGCCTTCTCTAACCTCT CC3'. Pengaturan PCR untuk COX-2 suhu $95^{\circ} \mathrm{C}$ selama 5 menit, $95^{\circ} \mathrm{C} 45$ detik, $46^{\circ} \mathrm{C} 45$ detik, $72^{\circ} \mathrm{C}$ 45 detik, diulang 35 siklus. Kemudian suhu $72^{\circ} \mathrm{C}$ selama 10 menit. HPRT digunakan sebagai kontrol internal dengan primer Forward 5'GCAGCCCTGGCGTCGTGATTAG3', Reverse 5'CCCCTTGAGCACACA GAGGG3'. Pengaturan suhu $95^{\circ} \mathrm{C}$ selama 5 menit, $95^{\circ} \mathrm{C} 30$ detik, $52^{\circ} \mathrm{C} 30$ detik, $72^{\circ} \mathrm{C} 30$ detik, diulang 35 siklus. Kemudian suhu $72^{\circ} \mathrm{C}$ selama 10 menit.

Hasil PCR dielektroforesis dalam gel agarose $2 \%$, dengan 50 volt selama 60 menit. Gel diamati di bawah sinar UV dan didokumentasikan dengan kamera digital. Hasil dokumentasi dianalisis menggunakan piranti lunak Scion Image for Windows. Analisis dilakukan dengan menentukan Optical Integrated Density (OID) dari masing-masing pita elektroforesis. Persentase penurunan ekspresi gen COX-2 pada kelompok perlakuan dibandingkan dengan kelompok kontrol. ${ }^{17,18}$ Hasil perhitungan dianalisis menggunakan one way ANAVA menggunakan SPSS 11.5 untuk membandingkan persentase penurunan ekspresi gen COX-2 antar kelompok perlakuan.

\section{Hasil}

\section{Sitotoksisitas Minyak Buah Merah}

Pada MTT Assay persentase kematian sel terbanyak didapatkan pada konsentrasi Buah Merah sebesar $500 \mu \mathrm{g} / \mathrm{mL}$, yaitu sebesar 98,25\%, sedangkan pada konsentrasi $200 \mu \mathrm{g} / \mathrm{mL}$ terjadi penambahan jumlah sel sebesar 1,41\% (Gambar 1). 


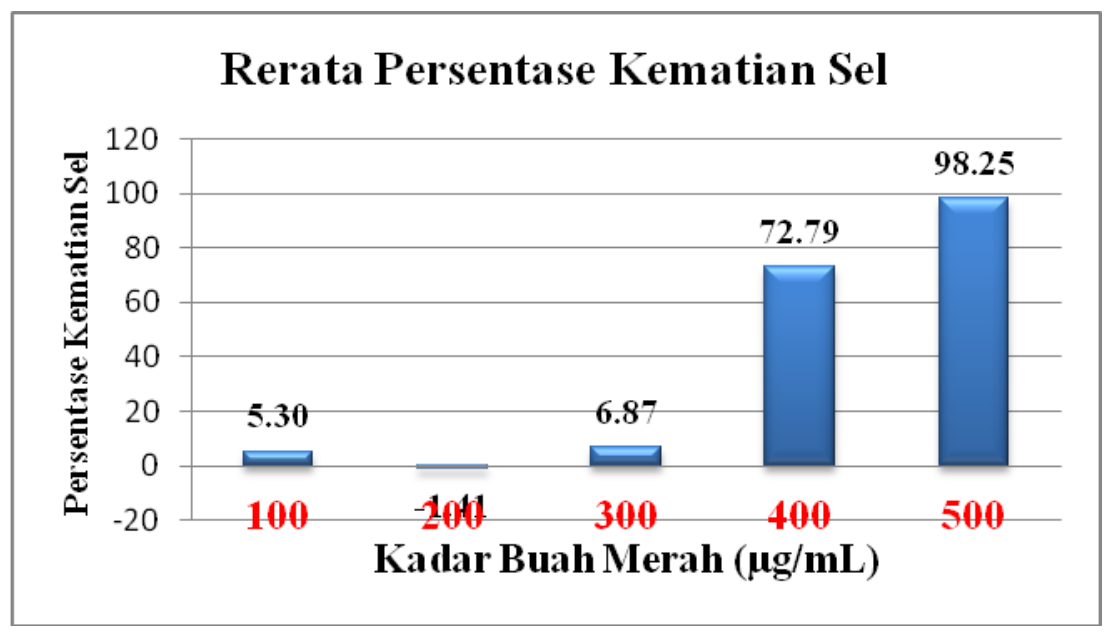

Gambar 1 Persentase Kematian Sel Raji setelah Perlakuan Buah Merah

Selanjutnya dihitung konsentrasi $\mathrm{LC}_{50}$ yaitu konsentrasi yang menyebabkan kematian $50 \%$ populasi sel menggunakan analisis regresi korelasi. Didapatkan rumus perhitungan: \% Kematian Sel $=-278,825+130,466 \log$ konsentrasi. LC $_{50}$ Buah Merah (Pandanus conoideus Lam.) terhadap Sel Raji adalah 331,4 $\mu \mathrm{g} / \mathrm{mL}$.

\section{Efek Minyak Buah Merah Terhadap Ekspresi Gen COX-2 pada Sel Raji}

Setelah perlakuan dengan Buah Merah, hasil PCR dengan primer HPRT dan COX-2 dielektroforesis dengan agarose $2 \%$ kemudian hasilnya dilihat dengan lampu UV dan didokumentasikan dengan kamera digital (Gambar 2).

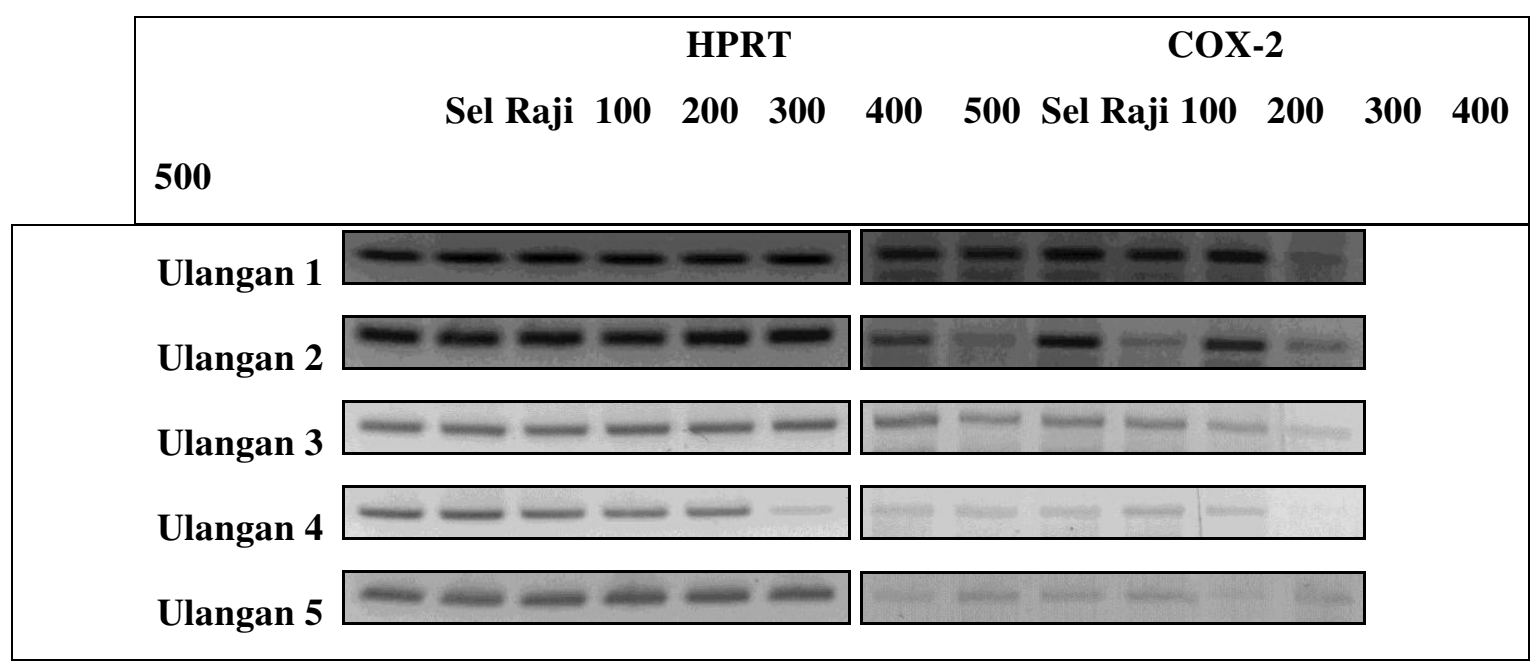

Gambar 2 Hasil Elektroforesis PCR HPRT dan COX-2 


\section{Research Article}

Pada dokumentasi hasil elektroforesis tampak adanya penipisan pita COX-2 pada kelompok perlakuan Buah Merah dengan kadar $500 \mu \mathrm{g} / \mathrm{mL}$. Hasil dokumentasi dianalisis dengan piranti lunak Scion Image for Windows untuk menentukan OID dari masing-masing pita elektroforesis. Hasil pengukuran OID COX-2 dari kelompok perlakuan dibandingkan dengan kontrol (Sel Raji) sehingga didapatkan angka persentase penurunan (Gambar 3).

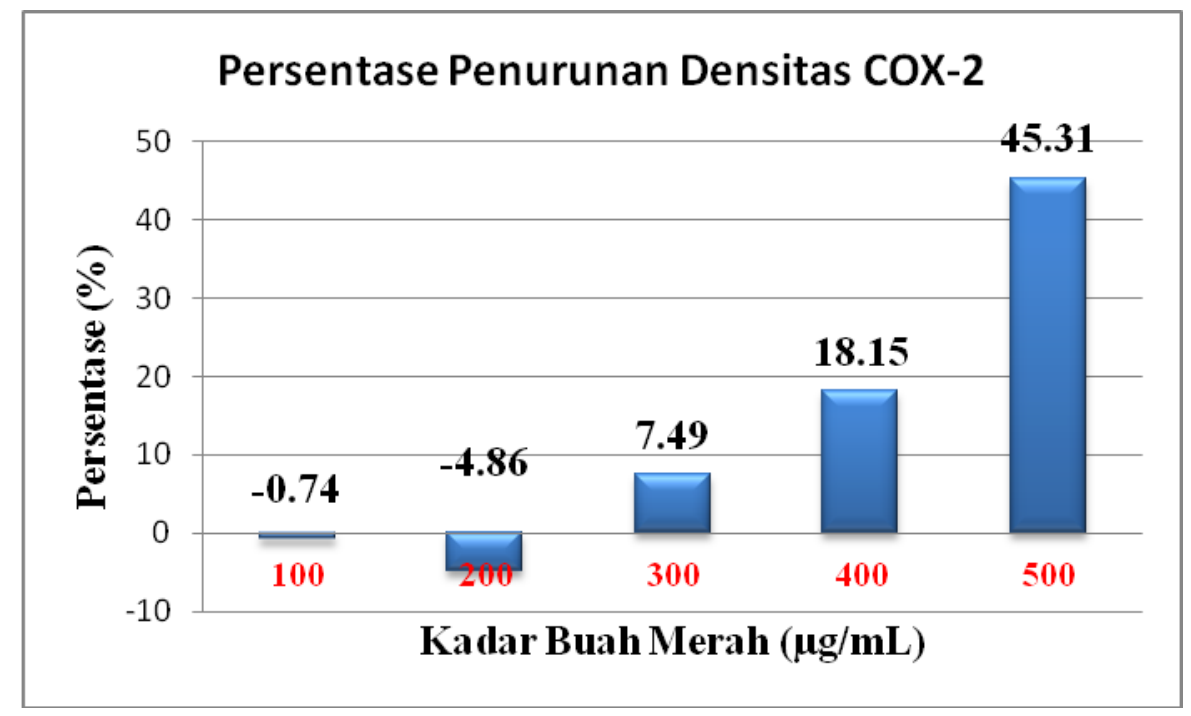

Gambar 3 Persentase Penurunan Optical Integrated Density COX-2

Hasil analisis statistik dengan metode ANAVA satu arah menunjukkan bahwa nilai $\mathrm{F}=$ 4,31 dan $\mathrm{p}=0,011(<0,05)$. Analisis uji Duncan menunjukkan bahwa persentase penurunan ekspresi gen COX-2 pada kelompok perlakuan dengan kadar Buah Merah $500 \mu \mathrm{g} / \mathrm{mL}$ berbeda nyata dengan kadar $100(\mathrm{p}=0,003), 200(\mathrm{p}=0,001)$, dan $300 \mu \mathrm{g} / \mathrm{mL}(\mathrm{p}=0,012)$, tapi tidak berbeda nyata dengan kadar $400 \mu \mathrm{g} / \mathrm{mL}(\mathrm{p}=0,06)$.

\section{Diskusi}

Hasil penelitian dengan MTT Assay menunjukkan minyak Buah Merah bersifat sitotoksik terhadap sel Raji. Hasil ini sesuai dengan penelitian sebelumnya pada sel karsinoma paru manusia (A549) secara in vitro yang hasilnya menunjukkan bahwa minyak Buah Merah dengan kadar $500 \mu \mathrm{g} / \mathrm{mL}$ dapat menekan pertumbuhan sel karsinoma tersebut. Hasil penelitian ini juga sesuai dengan penelitian yang menggunakan ekstrak n-heksan Buah Merah secara in vitro pada sel tumor kelenjar susu dengan konsentrasi efektif $0,14 \mathrm{gr} / \mathrm{mL}$, sedangkan pada penelitian yang menggunakan fraksi minyak dan fraksi air Buah Merah terhadap sel HeLa dan 


\section{Research Article}

sel K562, inhibitory concentration 50 ( $\left.\mathrm{IC}_{50}\right)$ untuk fraksi minyak untuk sel HeLa adalah 50,40 $\mu \mathrm{L} / \mathrm{mL}$ dan untuk sel K562 adalah $10,67 \mu \mathrm{L} / \mathrm{mL}$, sedangkan $\mathrm{IC}_{50}$ fraksi air untuk sel HeLa adalah $22,12 \mu \mathrm{L} / \mathrm{mL}$ dan untuk sel K562 adalah 13,99 $\mu \mathrm{L} / \mathrm{mL}^{10,11,19}$

Minyak Buah Merah dapat menekan ekspresi gen COX-2 dengan dosis efektif pada 500 $\mu \mathrm{g} / \mathrm{mL}$. Kemampuan Buah Merah dalam menurunkan ekspresi gen COX-2 ini mungkin dikarenakan kandungan senyawa kimia di dalamnya seperti $\beta$-karoten, $\beta$-cryptoxanthin dan vitamin E. ${ }^{10}$ Beta karoten dapat menghambat aktivitas NF-kB, yang merupakan faktor transkripsi penting untuk ekspresi gen COX-2 (Gambar 4). Senyawa carotenoid golongan xanthofil seperti $\beta$-cryptoxanthin dapat menghambat ekspresi COX-2 melalui supresi aktivasi NF-кB. Vitamin E dimetabolisme menjadi karboksikormanol yang merupakan inhibitor poten terhadap aktivitas COX-2.10,14,15

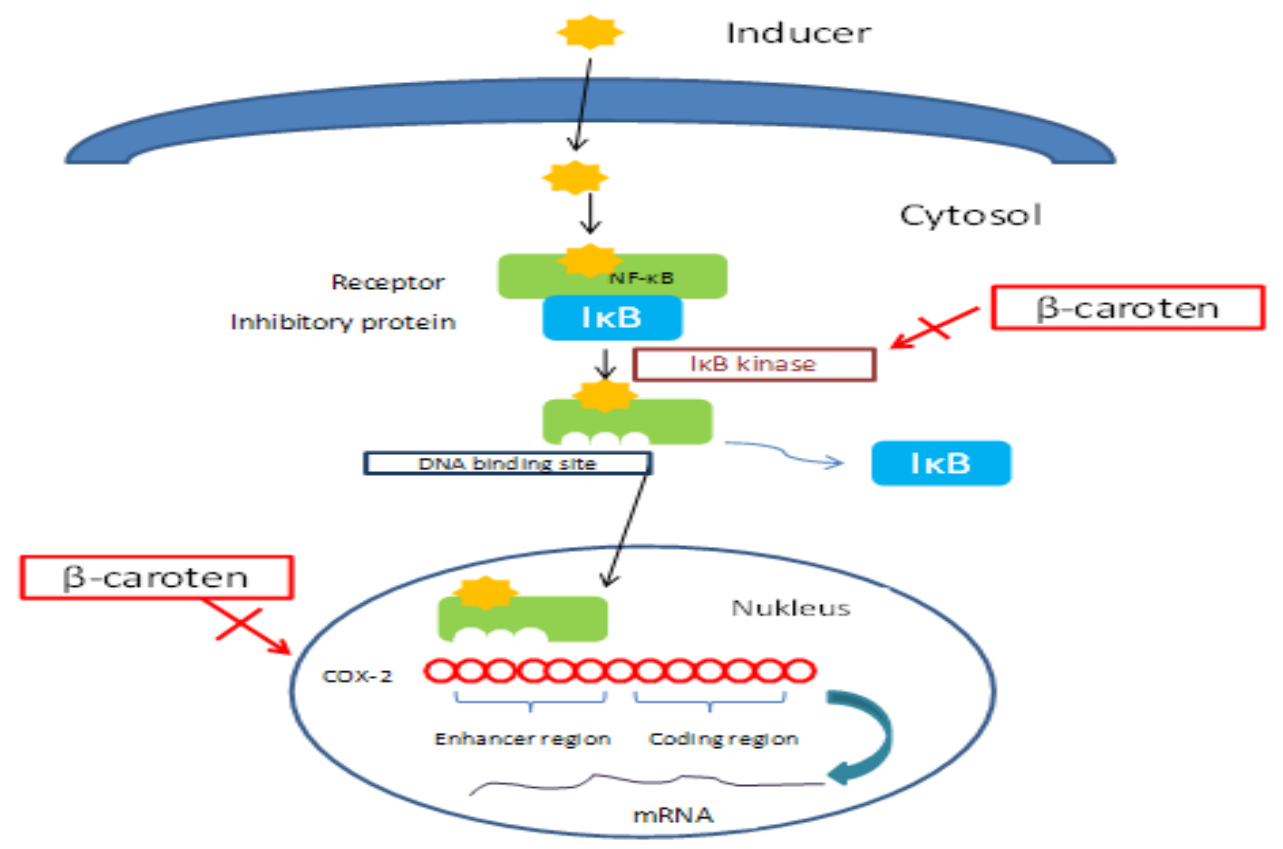

\section{Gambar 4 Mekanisme Kerja B-Caroten dalam Inhibisi NF-Kb Sebagai Faktor Transkripsi untuk Ekspresi Gen COX-2, Dimodifikasi ${ }^{17}$}

\section{Simpulan}

Buah Merah (Pandanus conoideus Lam.) berefek sitotoksik terhadap Sel Raji, dengan $\mathrm{LC}_{50}$ sebesar $331,42 \mu \mathrm{g} / \mathrm{mL}$ dan dapat menurunkan ekspresi gen COX-2 pada sel Raji dengan dosis efektif sebesar $500 \mu \mathrm{g} / \mathrm{mL}$. 


\section{Research Article}

\section{Daftar Pustaka}

1. Dinas Kesehatan. Mengenal kanker. 2007. Melalui <http://dinkesbonebolango.org> [06/07/2009] Internet.

2. Sajuthi Dondin. Ekstraksi, fraksinasi, karakterisasi, dan uji hayati in vitro senyawa biokatif daun dewa (gynura pseudochina (linn.) Dc.) sebagai antikanker, Tahap II. Buletin Kimia IPB 1 2001;75-9.

3. Smith G, Missailidis S. Cancer, inflammation and the AT1 and AT2 Receptors. J of Inflammation 2004;1:3

4. Zullies I, Agung EN, Winda W. Efek ekstrak etanol daun erythrina fusca lour (cangkring) terhadap penekanan ekspresi enzim siklooksigenase-2 pada kultur sel raji. Majalah Farmasi Indonesia 2006; 17(2):85-90.

5. Mazhar D, Gillmore R, Waxman J. COX and Cancer. Q J Med 2005; 98: 711-8.

6. Kuwano T, Nakao S, Yamamoto $\mathrm{H}$, et al. Cyclooxygenase 2 is a key enzyme for inflammatory cytokineinduced angiogenesis. Faseb J 2004; 18: 300-10.

7. National Cancer Institute. Executive summary of inflammation an cancer think tank. 2007. Melalui $<$ http:www.cancer.gov> [06/07/2009] Internet.

8. Brown J, DuBois R. Cyclooxygenase-2 in lung carcinogenesis and chemoprevention, Roger S. Mitchell lecture. Chest 2004; $125: 134$ S-40S

9. World Health Organization. Information exchange system : cyclooxygenase-2 (cox-2) inhibitor medicines. 2005. Melalui <http://www.who.int/medicines> [06/07/2009] Internet.

10. Surono I, Nishigaki T, Endaryanto A, Waspodo P. Indonesian biodiversities, from microbes to herbal plants as potential functional foods. J of the Faculty of Agriculture Shinshu University 2008; 44(1·2): 23-27.

11. Kumala S, Kusmardi, Indriatmoko D. Pengaruh ekstrak buah merah (pandanus conoideus lam.) Terhadap pertumbuhan in vitro limfosit dan sel tumor. Departemen Patologi Anatomi Fakultas Kedokteran Universitas Indonesia. 2007.

12. Mun'im A, Andrajati R, Susilowati H. Uji hambatan tumorigenesis sari buah merah (Pandanus conoideus Lam.) terhadap tikus putih betina yang diinduksi 7,12 Dimetilbenz(a)Antrasen (DMBA). Majalah Ilmu Kefarmasian 2006; III(3): 153-61.

13. Palozza P, Serini S, Maggiano N, Tringali G, Navarra P, Ranelletti F, et al. B-carotene downregulates the steady-state and heregulin- $\alpha$-induced cox-2 pathways in colon cancer cells. The J. Nutr 2005;135: 129-36.

14. Bai SK, Lee SJ, Na HJ, Ha KS, Han JA, Lee H, et al. B-carotene inhibits inflammatory gene expression in lipopolysaccharide-stimulated macrophages by suppressing redox-based nf- $\kappa \mathrm{b}$ activation. Experimental and Molecular Medicine 2005; 37(4): 323-34.

15. Jiang Q, Yin X, Lill M, Danielson M, Freiser H, Huang J. Long-chain carboxychromanols, metabolites of vitamin e, are potent inhibitors of cyclooxygenases. PNAS 2008; 105(51): 20464-9.

16. Pudjono, Sismindari, Widada H. Sintesis 2,5-bis-(4'-hidroksi benzilidin) siklopentanon dan 2,5-bis-(-4'klorobenzilidin) siklopentanon serta uji antiproliferatifnya terhadap sel heLa. Majalah Farmasi Indonesia 2008; 19(1): 48-55.

17. Panutsopulos D, Zafiropoulus A, Krambovitis E, Kochiadakis G, Igoumenidis N, Spandidos D. Peripheral monocytes from diabetic patients with coronary artery disease display increased bfgf and vegf mrna expression. J Translational Med 2003; 1(6): 1-11.

18. Van Q, Liu J, Lu B, Feingold K, Shi Y, Lee R, et al. Phospholipid scramblase-3 regulates cardiolipin de novo biosynthesis and its resynthesis in growing heLa cells. Biochem J 2007; 401: 103-9.

19. Nurheni SP. Manfaat buah merah untuk meningkatkan kualitas kesehatan. 2007. Melalui <http;//web.ipb.ac.id> [25/02/09] Internet. 